大腸癌と両側腎癌との同時性 3 重複癌の 1 例

\begin{tabular}{lllllll}
\multicolumn{8}{c}{ 都志見病院外科 } \\
山 & 本 & 達 & 高 野 尚 史 安 藤 静一郎 \\
亥 & 埜 & 恵 & 一 & 都志見 久令男 & &
\end{tabular}

大腸癌の術前検查て両側腎癌を発見し，切除術を施行しえた同時性重複癌の 1 例を報 告する.症例は，73歳男性．便潜血反応陽性のため注腸透視，大腸内視鏡を施行し盲腸 癌と診断, さらに術前 CT で両側腎臓に腫瘤を発見し, 血管造影にて両側腎癌と診断し た. 他葴器に転移のないことを確認後, まず右半結腸切除, 右腎部分切除術を施行した。 初回手術より，4 週間後, 左腎摘出術を施行した。術後, 腎不全は回避できた. 大腸癌 は，高分化腺癌，深達度 $\mathrm{m}$, リンパ節転移は認めなかった．右腎癌は， alveolar type， common type, clear cell subtype の腎細胞癌, 左腎癌は, papillary type, common type, clear cell subtype の腎細胞癌であった.リンパ節転移は認めなかった。術後経過良好で， 現在再発なく経過観察中である。

臬引用語：大腸癌, 腎癌, 重複癌

\section{緒言}

診断技術の向上により無症状で発見される癌が増加 し，重複癌に遭遇する機会も増加している．今回われ われは癌検診を契機に発見された大腸癌とその術前検 查で発見された両側腎癌に对して切除術を施行できた 症例を経験したので，文献的考察を加えて報告する。

\section{症例}

患者：73歳男性.

主訴：便潜血反応陽性.

家族歴：特記すべきことなし。

既往歴：50歳時, 肺結核.

現病歴：平成 7 年 4 月検診で, 便潜血反応陽性を指 摘され，精査加療目的で受診となった。

入院時現症：身長 $174 \mathrm{~cm}$ ，体重 $59 \mathrm{~kg}$ 。賽血，黄疸な し、肝脾腎および腹部腫㢚は触知せず。

入院時検查所見：一般検血, 血液生化学, 堅機能, 尿検査に異常は認められず，腫瘍マーカーも正常範囲 内であった（表 1 ).

注腸透視：盲腸に1'型の隆起性病変を認めた（図 1).

大腸内視鏡検査：盲腸に径 $3 \mathrm{~cm}$ の1'型の腫場を認 め，生検で高分化腺癌であった（図 1 ).
表 1 入院時及び初回手術後検査所見

\begin{tabular}{|c|c|c|}
\hline & 術前㭘㚗所見 & 切回手術後 \\
\hline WBC & $4,900 / \mathrm{mm}^{3}$ & $5,900 / \mathrm{mm}^{3}$ \\
\hline $\mathrm{RBC}$ & $462 \times 10^{4} / \mathrm{mm}^{3}$ & $329 \times 10^{4} / \mathrm{mm}^{3}$ \\
\hline $\mathrm{Hb}$ & $14.4 \mathrm{~g} / \mathrm{dl}$ & $10.2 \mathrm{~g} / \mathrm{dl}$ \\
\hline $\mathrm{Ht}$ & $42.6 \%$ & $30.1 \%$ \\
\hline PLT & $16.6 \times 10^{4} / \mathrm{mm}^{3}$ & $22.3 \times 10^{4} / \mathrm{mm}^{3}$ \\
\hline GOT & $22 \mathrm{IU} / l$ & $38 \mathrm{IU} / l$ \\
\hline GPT & $17 \mathrm{IU} / l$ & $57 \mathrm{IU} / l$ \\
\hline AIP & $262 \mathrm{IU} / l$ & $222 \mathrm{IU} / l$ \\
\hline LDH & $309 \mathrm{IU} / l$ & $319 \mathrm{IU} / l$ \\
\hline$\gamma-\mathrm{GTP}$ & $16 \mathrm{IU} / l$ & $33 \mathrm{IU} / l$ \\
\hline Glu & $95 \mathrm{mg} / \mathrm{dl}$ & $78 \mathrm{mg} / \mathrm{dl}$ \\
\hline $\mathrm{T} \cdot \mathrm{Bil}$ & $0.9 \mathrm{mg} / \mathrm{dl}$ & $0.5 \mathrm{mg} / \mathrm{dl}$ \\
\hline BUN & $16.2 \mathrm{mg} / \mathrm{dl}$ & $13.9 \mathrm{mg} / \mathrm{dl}$ \\
\hline Cre & $0.8 \mathrm{mg} / \mathrm{dl}$ & $0.7 \mathrm{mg} / \mathrm{dl}$ \\
\hline $\mathrm{Na}$ & $142 \mathrm{mEq} / l$ & $141 \mathrm{mEq} / \mathrm{l}$ \\
\hline $\mathrm{K}$ & $4.2 \mathrm{mEq} / l$ & $3.8 \mathrm{mEq} / l$ \\
\hline Alb & $4.1 \mathrm{~g} / \mathrm{dl}$ & $3.5 \mathrm{~g} / \mathrm{dl}$ \\
\hline CEA & $2.3 \mathrm{ng} / \mathrm{ml}$ & - \\
\hline CA19-9 & $26.9 \mathrm{U} / \mathrm{ml}$ & - \\
\hline 尿糖 & $(-)$ & $(-)$ \\
\hline 尿蛋白 & $(-)$ & $(-)$ \\
\hline 尿潜血 & $(-)$ & $(-)$ \\
\hline 24h クレアチニン & $74.8 \mathrm{ml} / \mathrm{min}$ & $83.9 \mathrm{ml} / \mathrm{min}$ \\
\hline クリアランス & & \\
\hline
\end{tabular}

腹部 CT 検查：右腎下極に径 $3.5 \mathrm{~cm}$, 左腎上極に径4 $\mathrm{cm}$ と左霄中央に径 $1.5 \mathrm{~cm}$ の low density area を認め

1996年 3 月18日受付 1996年 6 月 5 日採用 


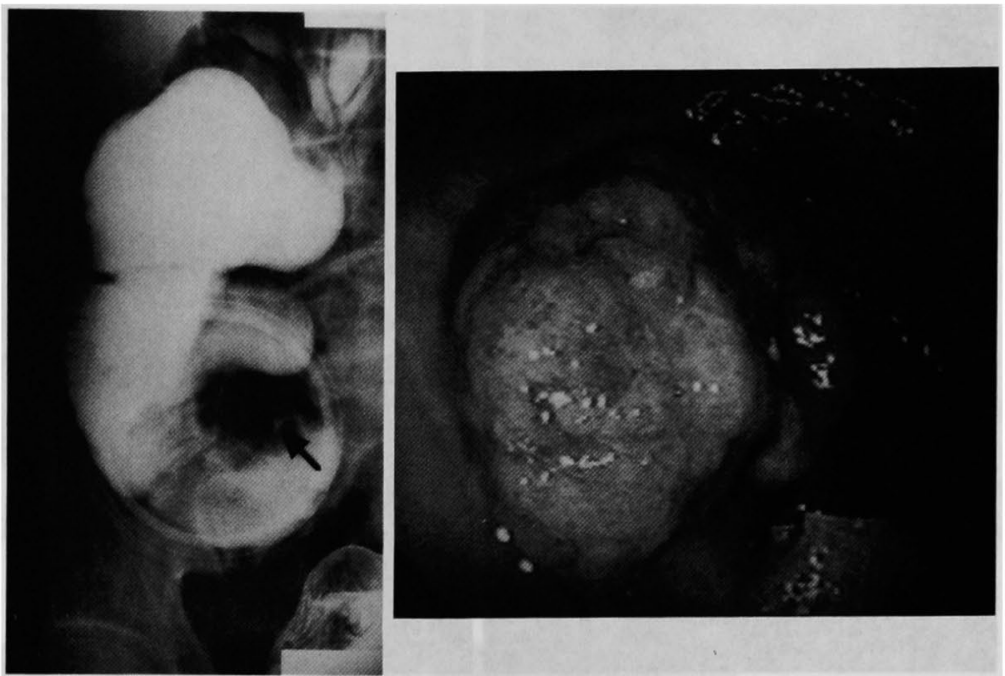

図 1 注腸透視（左）：で盲腸に径 $3 \mathrm{~cm}$ の 1 '型の隆起性病変を認めた. 大腸内視鏡検査（右）：で盲腸にカリフラワー状の1'型の腫瘍を認めた.
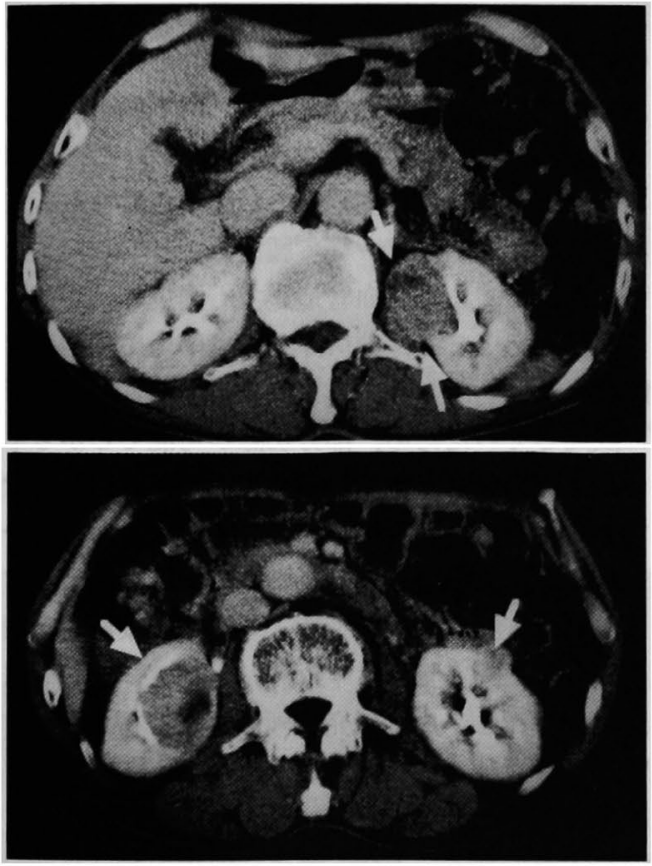

図 2 腹部 CT 検査：右腎下極に径 $3.5 \mathrm{~cm}$, 左腎上極 に径 $4 \mathrm{~cm}$ と左腎中央に径 $1.5 \mathrm{~cm}$ の low density area を認めた.

た（図 2 ). dynamic CT で濃染し腎癌が疑われた。

腎動脈造影：両側腎腫瘤は, hypervascular で, 不整 な腫瘍血管を認め, 毛細管相では腫湯濃染像が認めら
れた（図 3 ).

以上より, 盲腸癌, 両側腎癌と診断し二期的に根治 手術が可能と判断し平成 7 年 5 月15日初回手術を施行 した.

初回手術所見：右傍正中切開にて開腹. 肝転移, 腹 膜播種, 腹水は認めなかった. まず, 結腸右半切除術 （D2郭清）を施行し，右腎を脱転した．腎癌は Gerota 筋膜内に限局し，リンパ節腫脹も認めなかった．腎茥 部を露出し腎動静脈を遮断, 氷片で腎臓を冷却しつつ 腎部分切除術を施行した。遮断時間は25分であった。

摘出標本および病理組織所見: 大腸病変は, 盲腸に 存在し, $3.5 \times 3.0 \mathrm{~cm}$, の IIa の大腸癌であった (図 4 ). 手術的進行度は, T1, N0, P0, S0, M0, stage 0であっ

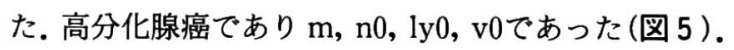
右腎病変は, 径 $4.5 \times 3.0 \mathrm{~cm}$ の球状腫瘤で, 割面は黄白 色であった (図4). alveolar type, common type, clear cell subtype の腎細胞癌, G1, INF $\beta, \mathrm{pT} 2, \mathrm{pN} 0$, pM0, pV0であった（図 5 ).

術後, 腎機能は正常範囲内, 24時間クレアチニンク リアランスは $83.9 \mathrm{ml} / \mathrm{min}$ と良好であったので（表 1 ), 左腎摘出術が可能と判断し, 初回手術 4 週間後に 左腎摘出術を施行した。

手術所見：左傍正中切開にて開腹し，腎茎部を露出 し腎動静脈を結紮切離後, Gerota 筋膜ごと左腎副腎を 脱転し傍大動脈リンパ節を郭清, 左腎摘出術を施行し た. 

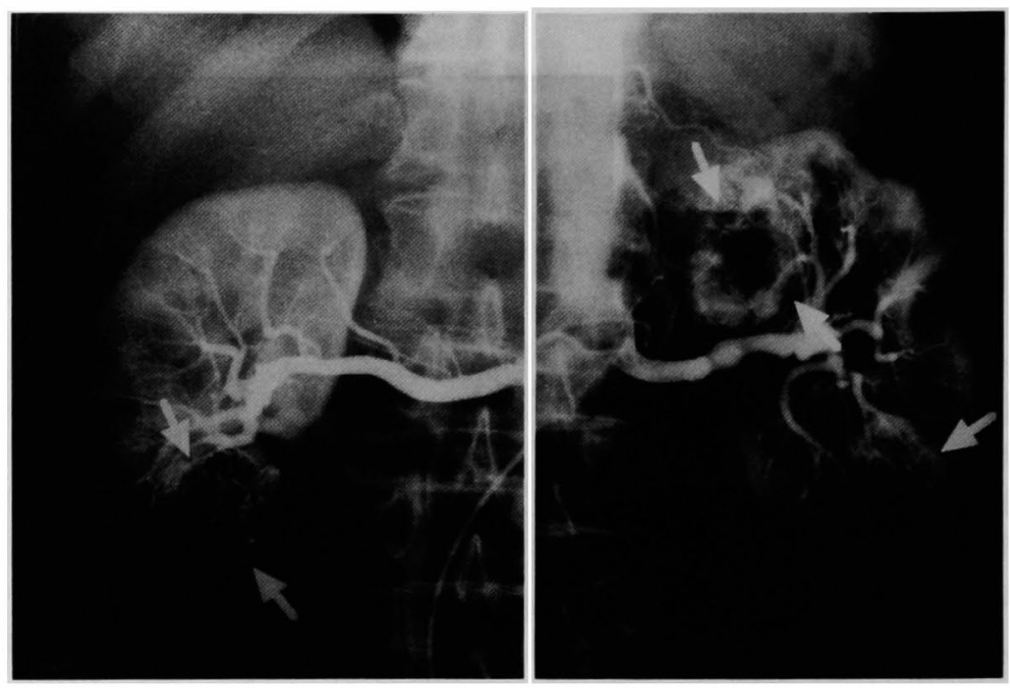

図 3 堅動脈造影：腎動脈造影で両側腎腫瘤は, hypervascular で, 不整な腫瘍血管を 認めた。

摘出標本および病理所見：径 $4.0 \times 3.0 \mathrm{~cm}$, および径 $1.5 \times 1.5 \mathrm{~cm}$ の腫瘤を認めた。割面は, 黄色調であった (図6). papillary type, common type, clear cell subtype の腎細胞癌であった. G1, INF $\alpha, \mathrm{G} 1, \mathrm{pT} 2$, pN0，pM0，pV0であった（図6).

術後一過性の堅機能低下を認めたが血液透析を施行 するには至らず軽快退院した。現在再発なく，経過観 察中である。

\section{考察}

診断技術の進歩に伴い重複癌が増加しているが，臓 器の組み合わせによっては治療の選択に苦慮する場合 が少なくない. 今回われわれは，早期大腸癌と両側腎 癌の切除例を経験したが, この組み合わせは腎癌が両 側性に存在するため手術法の選択に苦慮した。

大腸癌からみた重複癌の頻度は，5.1\%～8.38\%で， 重複した他藏器癌は, 胃癌が最も多く, 続いて子宮癌,

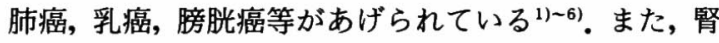
癌からみた重複癌の頻度は, $11 \%$ 19\%で, 重複した 他葴器癌は, 胃癌が最も多く, 肺癌, 他の泌尿器癌,

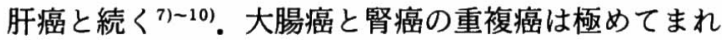
で，自験例の大腸癌と両側腎癌の組み合わせは，われ われの検索しえた限りでは報告例はみあたらない.

重複癌の治療は, 癌の進行度, 予後, 臟器固有の機 能等を考慮して選択されるが，自験例のごとく，両側 腎癌の場合には, 腎機能温存下に根治手術が可能であ るか否かが最大の焦点となる，腎癌に対する腎保存的
手術の適応は, 両側腎癌, 単腎に発生した腎癌, 対側 腎機能が大きく障害されている場合などで，通常の腎 摘出術を施行すれば，透析が必要と成る場合とされて いる ${ }^{11}$. 自験例では, 両側腎に腫瘤を認め, しかも両側 は多発であるため, 一側腎癌の転移の可能性も否定で きなかった. CT, エコー等で腫大したリンパ節や遠隔 転移を認めず，また，血管造影でも腫場栓は認めず， 仮に転移であっても部分切除と腎摘出術で根治手術が 可能であると判断した，右腎癌は，単発性であり堅下 極に限局していたため, 部分切除が可能でしかも幸い なことに盲腸癌に対する結腸右半切除と同一術野で施 行できるため, 初回手術に結腸右半切除と右腎部分切 除を施行した。術後経過は良好で, 右腎機能が正常で あることを確認し, 初回手術より 4 週間後に左腎摘出 術を施行した，盲腸癌は早期癌，腎癌は，左右で組織 型が異なることから，原発性両側腎癌と判断した。術 後腎不全は回避でき，軽快退院した．現在再発なく経 過観察中である.

画像診断の進歩により，無症状腎癌の発見される頻 度が増加するに伴い, 腎癌関連重複癌に遭遇する機会 が増えると予想される，その治療にあたっては，腎機 能と根治性のバランスを考慮した術式の選択が重要で あると思われた。

\section{結 語}

大腸癌と両側腎癌の同時性重複癌切除例を経験し た。たとえ両側腎癌合併重複癌であっても症例によっ 

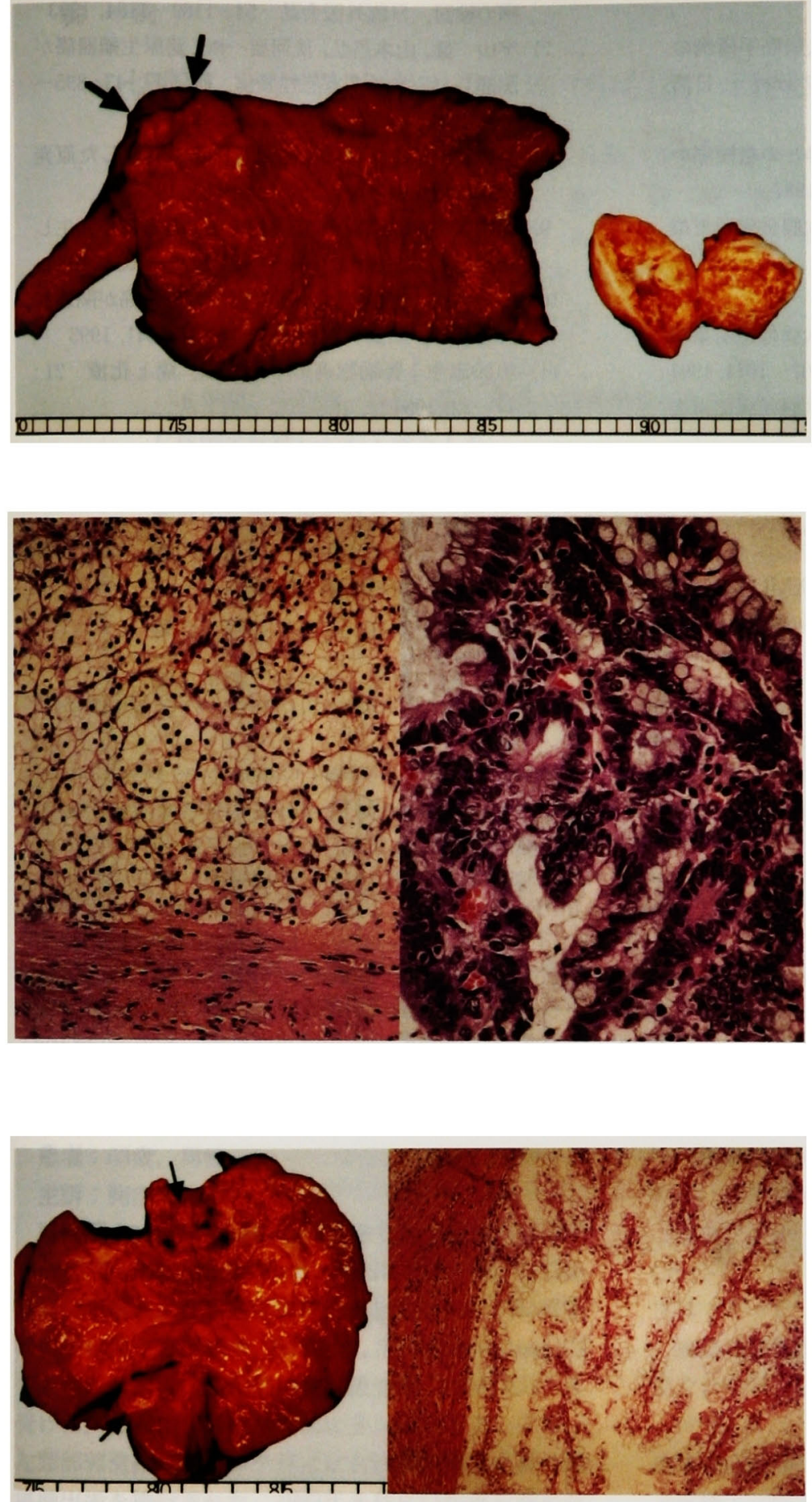

ては腎機能を温存しつつ，根治性を損なわない治療法 の選択が可能であることを実感した。
図 4 切除標本：盲腸に $3.5 \times 3.0$ $\mathrm{cm}$ ，の IIa の大腸癌を認めた。右 腎病変は, 径 $4.5 \times 3.0 \mathrm{~cm}$ の球状 腫瘤で厚い織維性被膜に覆われ, 割面は黄白色であった。

図 5 病理組織所見：盲腸癌（右, $\mathrm{HE}$ 染色 $\times 100)$ 高分化腺癌, $m$, n0, $1 \mathrm{y}(1), \mathrm{v} 0$ であった。腎病変 (左, HE 染色 $\times 100)$ alveolar type, common type, clear cell subtype の腎紐胞癌であった。

図 6 左霄摘出標本：(左) 佳 $4.0 \times$ $3.0 \mathrm{~cm}$ および径 $1.5 \times 1.5 \mathrm{~cm} の$ 腫溜を認めた。割面は，黄色調で あった。病理組織(右, HE 染色 $\times$ 200) papillary type, common type, clear cell subtype の腎細胞 癌であった。

文献

1）中塚博文, 西龟正之, 田村泰三他：大晹と他缄器と の重複癌の検討。日消外会誌 $15 ： 1785 \quad 1789$, 
1982

2) 羽田野 隆：他臓器の重複をみた大腸癌手術例の 検討一自験例11例と本邦文献165例の分析一. 日消 外会誌 $15: 807-818,1982$

3）関根 媇, 須田䔨夫：大腸と他葴器との重複癌の 検討. 日消外会誌 $20 ： 765-771,1987$

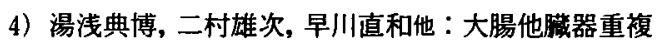
癌の臨床的検討. 日消外会誌 $23 ： 2370-2375$, 1990

5）松井成生, 吉川宣輝, 土屋祐一他：大腸他臟器重複 症例の検討. 日臨外医会誌 $52: 1007-1011,1991$

6）木村臣一, 岩垣博巳, 淵本定儀他：大腸他蔵器重複
癌の検討. 日臨外医会誌 $54: 1180-1184,1993$

7) 宇山 健, 山本昌弘, 淡河要一地: 泌尿生殖器癌が 関連した原発性多重悪性䭪場. 西日泌 $43: 895-$ 899,1981

8）三方律治，木下健二：泌尿器科癌が関連した原発 性重複癌. 癌の臨 $29: 183-186,1983$

9）船木広英, 鈴木信行, 安達雅史他：腎と胃に発生し た重複癌の 2 症例. 泌紀 31:1629-1634, 1985

10）三方律治，今尾貞夫，小松秀樹：堅細胞癌が関連し た重複癌. 日臨外医会誌 $54: 537-541,1993$

11）垣添忠生：腎細胞癌の手術療法。癌と化療 21 : $17-22,1994$

\title{
A CASE REPORT OF SYNCHRONOLUS TRIPLE CANCER OF THE COLON AND BILATERAL KIDNEYS
}

\author{
Tatsuhito YAMAMOTO, Naofumi TAKANO, Seiichirou ANDOH, \\ Keiichi INO and Kureo TSUSHIMI \\ Department of Surgery, Tsushimi Hospital
}

A case of synchronous triple cancer of the colon and bilateral kidneys, which were diagnosed preoperatively and resected successfully is reported.

A 73-year-old man was referred to the hospital for occult blood. A cecal cancer was revealed by barium enema and colonoscopy, and bilateral renal tumors were visualized by abdominal CT. Aortography showed hypervascular tumors in the bilateral kidneys, which were diagnosed as renal cancer.

After no often organ metatasis was confirmed a right hemicolectomy and right partial nephrectomy were performed simultaneously. Four weeks after the initial operation, a left radical nephrectomy was performed. Renal dysfunction was not experienced later. The cecal cancer was histologically diganosed as weil differentiated adenocarcinoma, with cancer cells confined within mucosa. Pathological diagnosis of the right renal lesion was alveolar type, common type and clear cell subtype of the renal cell carcinoma, and that of the left renal lesion was papillary type, common type and clear cell subtype of the renal cell carcinoma. No lymph node metastasis or vascular invasion was noted. The postoperative course was uneventful and the patient is strictly followed up. 